\title{
Identification and distribution of intermediate host snails in Mecha woreda, Amhara, North West of Ethiopia
}

\begin{abstract}
During summer, July 2016, Five kebeles of Mecha woreda were selected randomly and all the potential habitat of snails were visited including edges of springs, irrigation canals ,swamps, dam areas and some moist bushy places covered with plants. Five different kinds of snail genus were collected and identified as $46.1 \%$ land snails of the genus Helix, $23.7 \%$ Lymnaea, 13.2\% Bulinus, and 9.2\% Planorbin, and 7.9\% Oncomelania. The majority of the land snails being found in moist bushy biotopes, the Lymnaea in swampy and irrigation canals whereas most of Bulinus, Planorbis, and Oncomelania being commonly found at the edges of rivers and near dams. Then in conclusion, as evidenced from the study, the study area is conducive environment for survival of snail intermediate host and overall prevalence of Fasciola species.
\end{abstract}

Volume 2 Issue 5 - 2018

\author{
Desalew Salew,' Abaineh Munshea ${ }^{2}$ \\ 'Amhara Public Health Institute, Ethiopia \\ ${ }^{2}$ Department of Biomedical Science, Bahir Dar University \\ Faculity of Science, Ethiopia
}

Correspondence: Desalew Salew, Amhara Public Health Institute, Bahir Dar, Po box 477, Ethiopia,

Email desalew13।@gmail.com

Received: September 12, 2018 | Published: October 05, 2018

\section{Introduction}

\section{Back ground of the study}

Snails are the common intermediate hosts of most parasitic diseases of animals..$^{1-3}$ In the study area, small scale traditional practices using small streams and large scale irrigational practices using Koga dam are the common life supporting activities by the community of Mecha district. These activities may create suitable condition for survival of snail intermediate hosts and are expected to increase the risk of water born trematode parasites. In addition to this, the sheep in the study area usually graze at natural fields and drink at ponds that are suitable for the snail intermediate hosts of Fasciola ${ }^{4}$ Mecha district (Merawi) is one of the areas where environmental conditions and altitude of the area is conducive for the occurrence of snail hosts. However little information is available about its type and distribution in the study area. Any intervention that improves the productivity of farm animals is important in creating wealth and improving the standard of living of resource-poor farmers of Ethiopia. Therefore, there is a need for the development of good preventive and control measures against intermediate host snails in the study area through improved programs.

\section{Significance}

Thus, the purpose of this study is to determine the type and distribution of intermediate host snails in the study area. More over to help the stakeholders to take actions, prevention and control measures, and the study may also help as a source of information for future further research on the field in the study area.

\section{Objectives}

General objective: To explore the type and distribution of host snails in Mecha woreda.

\section{Specific objective}

i. To association of different snail genus at different environmental temperature in Mecha district.

ii. To explain the distribution of snail genus at different biotopes of Mecha district.

iii. To describe the distribution of snail genus in different land cover (substrate in Mecha district.

\section{Methods}

\section{The study area}

The study was conducted in Merawi town the main town of Mecha district of west Gojjam zone in Amhara regional state, North west of Ethiopia located about $525 \mathrm{~km}$ North West of Addis Ababa and $34 \mathrm{~km}$ South East of Bahir Dar the capital city of Amhara region. In Mecha, district the climatic condition, alternate between along summer rainfall and winter dry season with mean annual rainfall of $1500-2200 \mathrm{~mm}$. The mean temperature is between $24-27^{\circ} \mathrm{C}$ and altitude ranges from 1800 to $2500 \mathrm{~m}$.a.s.l. The study area is located at latitude $10^{\circ} 30^{\prime} \mathrm{N}$ and longitude $37^{\circ} 29^{\prime} \mathrm{E}$. The land is covered by Savanna grassland and bush lands vegetation. Agriculture is the main economic sector in the study area. The main agricultural activities currently practiced include irrigation (Modern and traditional) and mixed farming. The major agricultural products seasonally harvested include sorghum, maize, teff, wheat and other legume groups. In this district there are 192,556 cattle, 148,971 ovine, 23,106 equine and 204,181 poultry. ${ }^{5}$

During summer, July 2016, Five kebeles of Mecha woreda were selected randomly and all the potential habitat of snails were visited including edges of springs, irrigation canals, swamps, dam areas and some moist bushy places covered with plants. In the collection, snails visible to the naked eye floating on the water surface and moist mud were picked by hand using glove, watery areas that were deep and full of vegetation were searched by using cloth that can pass water through and which is tied to a long stick according to. ${ }^{6}$ The collection of snails is carried out at the morning and after rains, when the environmental temperature relatively low and humidity is available suitable for snail survival. Collection of snails was performed after rains by scooping and or hand picking conducted by two people at each site for $20 \mathrm{~min}^{7}$ Snails were identified morphologically using a field guide to African freshwater snails (Figure 1). ${ }^{8,9}$ 


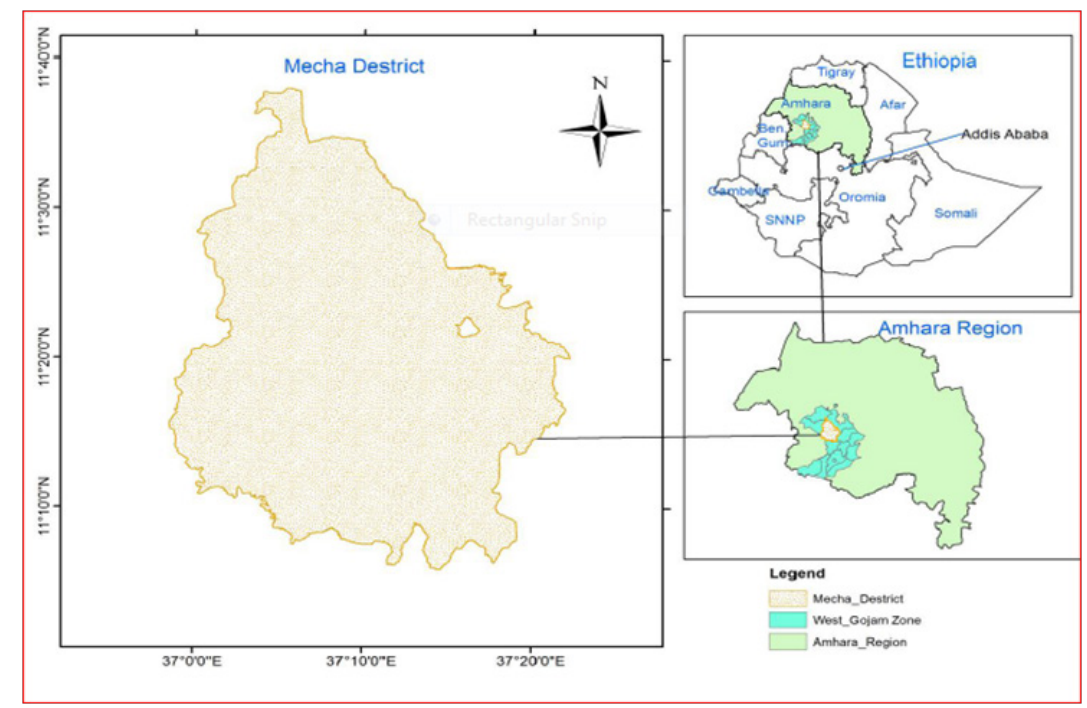

Figure I Map of the study area.

\section{Results}

\section{Distribution of snail genus}

In the present study, from the result of snail survey, five types of snail genus were distinguished. The distribution of different snail genus in five biotopes showed that genus Helix, Lymnaea, Bulinus, Planrbin and Oncomelania exist in 46.1\%, 23.7\%, 13.2\%, 9.2\%, and 7.9\% respectively. That was 35 Helix, 18 Lymnaea, 10 Bulinus, 7 Planorbis, and 6 Oncomelania (Table 1).

Table I The distribution of different snail genus at different environmental factors

\begin{tabular}{|c|c|c|c|c|c|c|c|c|c|c|c|}
\hline \multirow[b]{2}{*}{ Factor } & & \multicolumn{6}{|c|}{ Number of snails collected in each genus } & \multirow{2}{*}{ 95\%.Cl. } & \multirow{2}{*}{ DF } & \multirow{2}{*}{$\chi^{2}$} & \multirow{2}{*}{ p-value } \\
\hline & & $\mathbf{h}$ & $\mathbf{I}$ & b & $\mathbf{p}$ & $\mathbf{o}$ & sum & & & & \\
\hline \multirow{5}{*}{ Land cover } & Vegetation & 20 & 3 & 2 & 2 & 0 & 27 & $0.00-0.039$ & 12 & 23.244 & 0.013 \\
\hline & Leaf litter & 7 & 12 & 4 & 3 & 2 & 28 & & & & \\
\hline & Mud & 7 & 3 & 4 & 2 & 4 & 20 & & & & \\
\hline & others & 1 & 0 & 0 & 0 & 0 & 1 & & & & \\
\hline & total & 35 & 18 & 10 & 7 & 6 & 76 & & & & \\
\hline \multirow{6}{*}{ Biotope } & Moist bushy & 23 & I & 0 & 0 & 0 & 24 & $0.00-0.039$ & 16 & 89.089 & 0 \\
\hline & Swampy area & 2 & 8 & 0 & 0 & 0 & 10 & & & & \\
\hline & Irrigation canals & 3 & 7 & I & 0 & 0 & 11 & & & & \\
\hline & Stream sides & 7 & 0 & 2 & 3 & I & 13 & & & & \\
\hline & Dam area & 0 & 2 & 7 & 4 & 5 & 18 & & & & \\
\hline & total & 35 & 18 & 10 & 7 & 6 & 76 & & & & \\
\hline \multirow{4}{*}{ Temperature } & $(10-15)^{\circ} \mathrm{C}$ & 5 & 6 & 4 & 4 & 4 & 23 & $0.00-0.039$ & 8 & 25.845 & 0 \\
\hline & $(16-20)^{\circ} \mathrm{C}$ & 9 & 10 & 5 & 2 & 2 & 28 & & & & \\
\hline & $(20-25)^{\circ} \mathrm{C}$ & 21 & 2 & I & I & 0 & 25 & & & & \\
\hline & total & 35 & 18 & 10 & 7 & 6 & 76 & & & & \\
\hline \multirow{3}{*}{$\begin{array}{l}\text { Environmental } \\
\text { moisture }\end{array}$} & Morning & 20 & 10 & 7 & 3 & 3 & 43 & $0.809-0.954$ & 4 & 1.388 & 0.882 \\
\hline & After rain & 15 & 8 & 3 & 4 & 3 & 33 & & & & \\
\hline & total & 35 & 18 & 10 & 7 & 6 & 76 & & & & \\
\hline
\end{tabular}

\section{Association between biotope and snail genus} distribution

As shown below (Figure 2), from the result of the present study,
$65 \%$ of helix is found in moist bushy area, $83.33 \%$ of Lymnaea are found in swampy and irrigated areas, $70 \%$ of Bulinus are found near dam areas, all of the Planorbis are found near stream (sides and dams). 
$83.33 \%$ of the Oncomelania are found near dam areas. Statistical analysis showed that there is a significant $(\chi 2=89.089 ; \mathrm{p}=0.000)$ association between the distribution of snail genus and habitat.

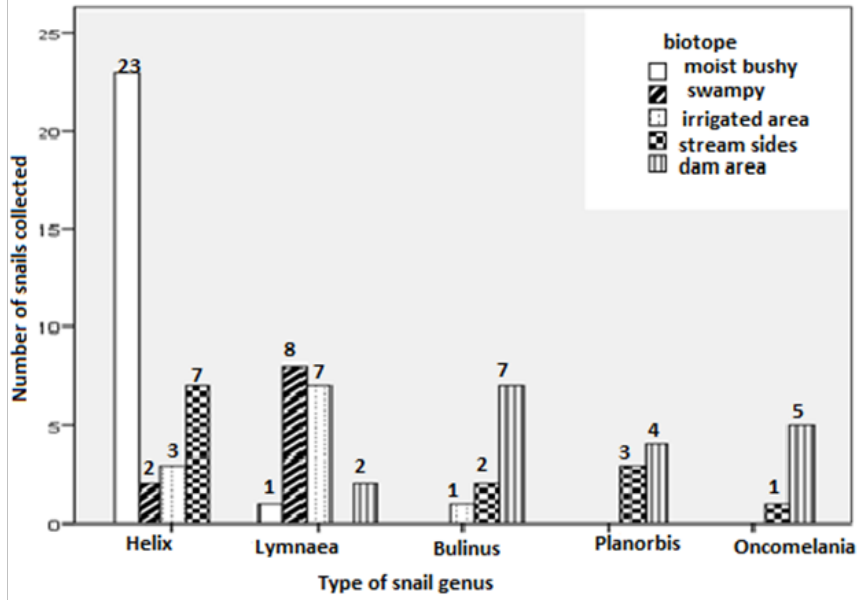

Figure $\mathbf{2}$ The distribution of snail genus in different biotopes.

\section{Association between land cover and snail genus distribution}

The result of the present study showed that most of the genus helix was found in vegetation cover, many of the Lymnaea are found in leaf litter, most of the genus Oncomelania are found in leaf litter and mud. Result of the snail survey indicated that there was a statistically significant $(\chi 2=23.244 ; p=0.039)$ association between the distribution of different snail genus and land cover of the place where snails are found (Figure 3).

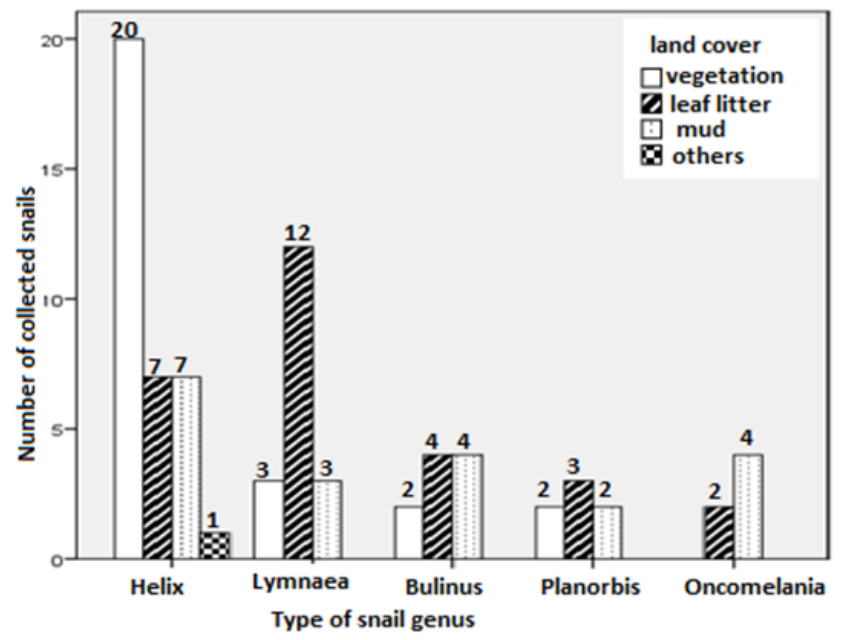

Figure 3 The distribution of snail genus collected in different land cover (substrate).

\section{The association of temperature with snail genus identification}

As it is shown (Figure 4), sixty percent of helix snails were found at temperature from $(21-25)^{\circ} \mathrm{c}, 55.5 \%$ of Lymnaea were found at (15$20)^{\circ} \mathrm{c}, 50 \%$ of Bulinus at $(16-20)^{\circ} \mathrm{c}, 57.1 \%$ of Planorbis at $(10-15)^{\circ} \mathrm{C}$ and $66.66 \%$ of Oncomelania at $(10-15)^{\circ} \mathrm{c}$. From the statistical analysis of the present study there exists a significant $(\chi 2=25.845 ; \mathrm{p}=0.00)$ association between temperature during snail collection and the type of snail genus collected.

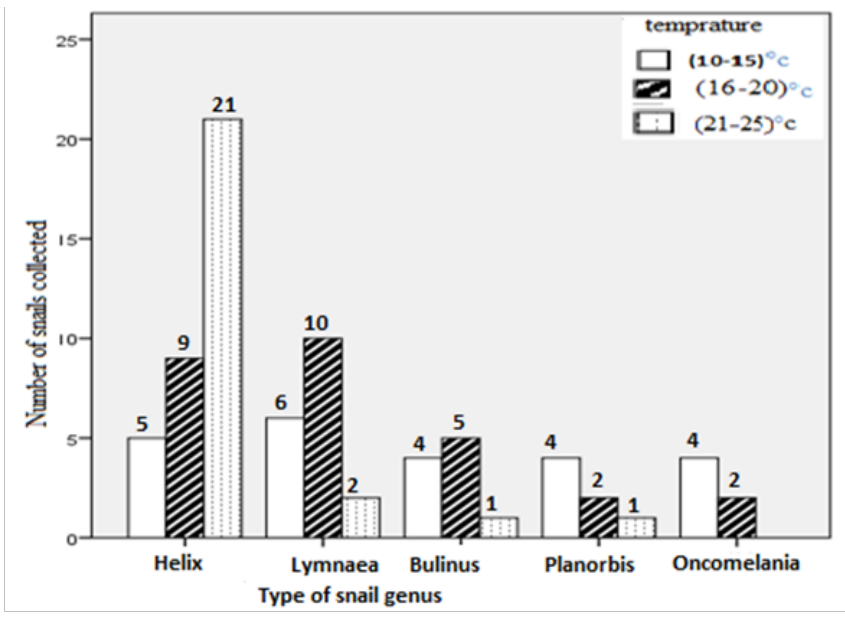

Figure 4 Association of snail genus at different environmental temperature.

\section{Discussion}

The snail survey carried out in 15 biotopes of the study area revealed the presence of five genera of snail. These include genus Helix, Lymnea, Bulinus, Planorbis, and Oncomelania. Of which, the most commonly occurring was the non-vector snail species belonging genus Helix and the least being genus Oncomelania. ${ }^{10}$

In relation to habitat preference of the snail species identified, it was observed that species of Helix genera were the most common in most bushy area while those of the members of genus Lymnea were mainly encountered in irrigation canals and swampy or paddy fields and the remaining three genera were commonly found near damps and edges of stream. ${ }^{11}$

The result of the present study is in support of the previous works by Boray, ${ }^{12}$ who reported the abundance of Oncomelania snails species in pools and dams, and the genus Planorbis and Bulinus snails are more common around stream side's and pools. Regarding Lymnea species, Michael ${ }^{13}$ and Dida et al. ${ }^{14}$ observed the abundance of this species in the irrigation channels because the water temperature and the vegetation found in irrigation cannels favors the development of the snails. In the present study, most of the genus Helix snails were collected on the surface of green leaves and many Lymnea snails were collected at leaf litter. The possible reason could be most of the land snails from genera Helix are herbivores feeding on plants and dwell mostly in vegetation, where as the Lymnea snails are detritivors that feed on various types of debris and organic matter in or on the surface of water bodies..$^{11,15,16}$ In the present study, a statistically significant association was observed between the environmental temperature during collection and the type of snail genus collected. Most of the Helix was collected at a range of temperature between $(21-25)^{\circ} \mathrm{C}$. In addition, nearly all of the Lymnea were collected at a temperature range from $(16-20)^{\circ} \mathrm{C}$ and most of the three genera Bulinus, Planorbis and Oncomelania were collected at low environmental temperature range of $(10-15)^{\circ} \mathrm{C}$. This may be due the fact that the majority of the land snails are terrestrial, have adapted, and survive the warm environmental temperature while the Lymnea and Bulinus snails were best adapted at temperature between $(16-20)^{\circ} \mathrm{C}$, although they can easily survive between $10^{\circ} \mathrm{C}$ and $35^{\circ} \mathrm{C} .{ }^{17}$ However, Oncomelania and Planorbis are more abundant at low water temperature. ${ }^{18,19}$

Lymnaid snails that act as intermediate hosts for Fasciola hepatica and Fasciola gigantic can be identified easily as compared to other freshwater snails. The opening of the Lymnaid snails is on the 
right when the snail is held with the spires pointing away from the viewer. When the apex of the spire is facing the viewer, the spires turn clockwise..$^{20}$ have developed morphological identification based on a dichotomous key. Lymnea snails were identified based on the morphological features described by Pham \& Phan $^{21}$ Allowing ${ }^{10}$ discrimination between $G$. truncatula and Radix sp. From the result of the present study, 18 Lymnea snails were collected. 5 of them are Galba truncatula and 13 of them are Lymnea natalensis. Identification of the snail species was made by studying the morphological features of the shell based on given traits for the major snail categories according to Brown. ${ }^{22}$ Lymneaa (Radix) natalensis measures $25 \mathrm{~mm}$ in length and $14.5 \mathrm{mmin}$ width. The spire is generally much less high than the aperture. The surface may have spiral rows of small transverse grooves, but always lacks strong spiral ridges of periostracum. (Galba) L. truncatula is 11 in length $6 \mathrm{~mm}$ in width (often smaller), comparatively small, with the spire about as high as the aperture and strongly convex whorls. Columela straighter and more broadly reflected than in L. natalensis according to Emile et al. ${ }^{23,10}$

From the result of the present study, the most prevalent Fasciola species found in the study area was Fasciola hepatica. In contrast with this, the most abundant Lymnea species found was Lymnea natalensis the common intermediate host of Fasciola gigantica. ${ }^{24}$

The probable reason for this may be Fasciola species including Fasciola hepatica has wider range of hosts (not host specific) so may parasitize the Lymnea natalensis the common intermediate host of Fasciola gigantica so Lymnea natalensis may have acted as an intermediate host of the other Fasciola species, Fasciola hepatica. A review on this point demonstrated the existence of conflicting results. ${ }^{25}$ Reported negative infections of $R$. natalensis with $F$. hepatica. Dreyfuss ${ }^{26}$ reported successful infection of $R$. natalensis with fasciola hepatica in Malagasy. This may be because imperfection during identification of the two species. It may also be due to the difference in susceptibility of the two snail species in the process of parasite development in their body.

\section{Conclusion}

Five different kinds of snail genus were collected and identified as $46.1 \%$ land snails of the genus Helix, 23.7\% Lymnaea, 13.2\% Bulinus, and 9.2\% Planorbin, and 7.9\% Oncomelania. The majority of the land snails being found in moist bushy biotopes, the Lymnaea in swampy and irrigation canals whereas most of Bulinus, Planorbis, and Oncomelania being commonly found at the edges of rivers and near dams. Then in conclusion, as evidenced from the study, the study area is conducive environment for survival of snail intermediate host (Annex 1)..$^{27-28}$

\section{Recommendations}

Animals should be prevented either by keeping them away from these area or by fencing of dangerous areas and swampy areas should be well drained and also Strategic anthelmintic treatment with appropriate flukicicide drug should be administered.

\section{Acknowledgements}

First, I would like to express my deepest gratitude to my advisors Dr. Abaineh Munshea for his effort in advising me to conduct my research and providing me with valuable information and comment. I would like to express my thank to my friend Amare Seifu from National Institute of Bio diversity Conservation (IBC) in A.A. Ethiopia. A special word of thanks goes to my friends Belayneh
Kassa; Mahel Zeleke and Emebet Emirie for their all kind of support for the success of my task. Finally yet importantly, I would like to thank my wife w/o Marie Antie my Daughter Yeabsira and my son Beamlak for missing their time at their vulnerable age which I should spend with them, otherwise the success of my task was impossible.

\section{Conflict of interest}

The author declares that there is no conflict of interest.

\section{References}

1. de Kock KN, Wolmarans CT, Bornman M. Distribution and habitats of the snail Lymnaea truncatula, intermediate host of the liver fluke Fasciola hepatica, in South Africa. J S Afr Vet Assoc. 2003;74(3):117-122.

2. de Kock KN, Wolmarans CT, Bornman M. Distribution and habitats of Biomphalaria pfeifferi, snail intermediate host of Schistosoma mansoni, in South Africa. Water SA. 2004;30(1):29-36.

3. De Kock KN, Wolmarans CT. Distribution, habitats and role as intermediate host of the freshwater snail, Bulinus forskalii, in South Africa Onderstepoort Journal of Veterinary Research. 2005;72(2):165-174.

4. Ngategize PK, Bekele T, Tilahun G. Financial losses caused by ovine fasciolosis in the Ethiopian highlands. Trop Anim Health Prod. 1993;25(3):155-161.

5. MWRDAP. Mecha woreda information and communication department. Mecha woreda annual; 2012.

6. Yadeta. Epediomeology of bovine and ovine fasciolosis and the distribution of its snail intermediate host in western shoa DVM thesis faculity of veterinary medicine Addis Ababa University. Ethiopia; 1994.

7. Madsen H, Daffalla A, Karoum K, et al. Distribution of freshwater snails in irrigation schemes in the Sudan. J Appl Ecol. 1988;25(3):853-866.

8. Brown. Distribution and Habitate of the Snail Lymnaea Truncatula Intermidiate host of Liver fluke Fasciola Hepatica. In south Africa. 1994.

9. Christensen NO, Gotsche G, Frandsen F. Parasitological Techniques for Use in Routine Laboratory Maintenance of Schistosomes and for Use in Studies on the Epidemiology of Human and Bovine Schistosomiasis. Danish Bilharziasis Laboratory, Charlottenlund, WHO; 1998.

10. Pan American Sanitary Bureau. A Guide for the Identification of the Snail Intermediate Hosts of Schistosomiasis. In the Americas Scientific Publication world health organization, washington DC, USA; 1968.

11. Anna Lydig, Kari Lehtila. Factors conditioning the distribution of fresh water pulmonates, Biomphalaria spp., Bulinus spp., and Lymnea spp., in Babati District. Tanzania; 2009.

12. Boray Joseph C. Liver Fluke Disease in Sheep and Cattle. Primefact 446, Liver Fluke Disease in Sheep and Cattle. State of New South Wales through NSW Department of Primary Industries; 2007.

13. Michael A. Infection prevalence of ovine fasciolosis in irrigation schemes along the Upper Awash River Basin and effects of strategic anthelmintic treatment in selected upstream areas. MSc thesis, Addis Ababa University, Ethiopia. 2004. p. 76

14. Gabriel O, Dida MPH, Frank B. et al. Distribution and abundance of scistosomiasis and fasciolosis host snails along the Mara river in Kenya and Tanzania. 2014.

15. Rollinson D, Stothard JR, Southgate VR. Interactions between intermediate snail hosts of the genus Bulinus and schistosomes of the Schistosoma haematobium group. Parasitology. 2001;123(Suppl 1):S245-S260.

16. Van Damme D, Jorgensen A, Kristensen TK, et al. Bulinus truncatus. The IUCN Red List of Threatened Species; 2012. e.T156053A14903090.

17. WHO. Control of foodborne trematode infections. World Health Organization Technical Report Series. 1995;849:1-157. 
18. De Kock KN, van Eeden JA. Effect of programmed circadian temperature fluctuations on population dynamics of Biomphalaria pfeifferi (Krauss). South African Journal of Zoology. 1986;21(1):28-32.

19. De Kock KN. The effect of programmed circadian temperature fluctuations on population dynamics of Bulinus tropicus (Krauss) and Lymnaea natalensis Krauss (Gastropoda: Mollusca). Journal of the Limnological Society of SouthernAfrica. 1985;11(2):71-74.

20. Janssen AW, Vogel EF. Zoetwatermollusken van Nederland. 1965, Amsterdam: Nederlandse Jeugdbond voor Natuurstudie.

21. Pham SL, Phan DL. Parasitic diseases in livestock and preventive measures (in Vietnamese). Agriculture Press, Hanoi; 2000. p. 68-79.

22. Brown D. Freshwater Snails of Africa and Their Medical Importance. Taylor \& Francis, London, UK; 1994.

23. Hoskin GP. Medical and economic malacology. Malek EA, Thomas CC, editors. Academic Press, New York and London;1975.
24. Mandahl-Barth G. Intermediate host of Schistosoma. African Biomphalaria and Bulinus: 2. Bulinus. Bulletin of the World Health Organisation. 1957;17(1):1-65.

25. Hussein AN. Khalifa RM. Experimental infections with Fasciola in snails, mice and rabbits. Parasitology Research. 2008;102(6):1165-1170.

26. Dreyfuss G. Contribution à l'étude des émissions cercariennes et de la charge parasitaire post-mortem chez trois espèces de limnées infestées par Fasciola hepatica Linné ou par Fasciola gigantica Cobbold. Doctorate Thesis, Limoges, 1994, 246 p.

27. Brown, David S. Freshwater snails of Africa and their medical importance. Revised second edition. Taylor and Francis Inc. London; 2005.

28. Njau BC, Kasali OB, Scholtens RG, et al. The influence of watering practices on the transmission of Fasciola among sheep in the Ethiopian highlands. Vet Res Commun. 1989;13(1):67-74. 